\title{
Endring i diagnostikk og behandling av hyperbilirubinemi hos nyfødte
}

\author{
Sammendrag \\ Bakgrunn. Ved Sykehuset i Vestfold \\ ble retningslinjene for diagnostikk og \\ behandling av hyperbilirubinemi hos \\ nyfødte endret i 1994 og 2007. Fra 2006 \\ ble det innført generell screening for \\ ABO-immunisering. I denne artikkelen \\ beskrives konsekvensene av disse \\ endringene.
}

Materiale og metode. Blodtypeimmuniseringer, lysbehandling og utskiftningstransfusjoner ble prospektivt registrert i 21-årsperioden 1988-2008. Materialet ble analysert med utgangspunkt i tre kohorter: barn født 1988-93, 1994-2006 og 2007-8.

Resultater. Andelen nyfødte som ble lysbehandlet var $6,2 \%$ i perioden 1988-93 og 6,7\% i perioden 1994-2006. Fysiologisk hyperbilirubinemi var den hyppigste årsaken til lysbehandling i første kohort, mens prematuritetshyperbilirubinemi var den hyppigste årsaken i andre kohort. Andelen som fikk lysbehandling i $2007-8$ var 4,8\%. Blodutskiftning ble foretatt hos $0,02 \%$ av barna født 1994-2008 mot 0,2\% født 1988-93. Utskiftning ble foretatt hyppigere ved RhD-immunisering $(7,8 \%)$ enn ved $A B O$-immunisering $(2,0 \%)$. Generell screening for ABO-immunisering økte diagnostiserte tilfeller i populasjonen fra 2,1\% til 3,6\%. Det ble ikke diagnostisert noe tilfelle av kjerneicterus.

Fortolkning. Endring av retningslinjer i 1994 medførte at færre fullbårne barn fikk lysbehandling for hyperbilirubinemi, mens flere premature ble behandlet. Utskiftningstransfusjoner utføres langt sjeldnere nå enn før 1994. ABOimmunisering ble diagnostisert hyppigere i de årene hvor generell screening for tilstanden ble gjennomført.

\author{
Andreas Tønne \\ andreastonne@gmail.com \\ Alf Meberg \\ Barnesenteret \\ Sykehuset i Vestfold \\ 3103 Tønsberg \\ Helle Borgstrøm Hager \\ Sentrallaboratoriet \\ Sykehuset i Vestfold
}

Normalt stiger serum-bilirubinkonsentrasjonen de første dagene etter fødselen. Dette medfører utvikling av klinisk icterus hos de fleste nyfødte. Høye bilirubinnivåer medfører risiko for kjerneicterus, den kroniske formen for bilirubinencefalopati, som har en signifikant mortalitet og alvorlig morbiditet. Kjerneicterus forsvant nærmest etter innføring av utskiftningstransfusjon ved alvorlig hyperbilirubinemi i 1950-årene. De senere årene har det imidlertid vært rapportert flere slike tilfeller (1-4). Forebygging av kjerneicterus er en viktig perinatalmedisinsk oppgave.

Bedre forståelse av bilirubinets toksiske effekter på den nyfødtes hjerne og forståelse av mekanismene bak blodtypeimmunisering, har ført til utvikling av screeningprogrammer for å oppdage slike tilstander. I tillegg har man de siste 50-60 årene utviklet effektive behandlingsprinsipper som utskiftningstransfusjon, lysbehandling og immunglobulin til mor og barn (anti-D-profylakse til ikke-immuniserte RhD-negative barselkvinner som har født RhD-positive barn, immunglobulininfusjon til nyfødte med blodtypeimmunisering og raskt stigende serumbilirubinkonsentrasjon). Nyere forskning har vist at friske fullbårne barn tåler en høyere serum-bilirubinkonsentrasjon enn tidligere antatt (5-7) og støtter opp om en mindre aggressiv holdning til behandling av hyperbilirubinemi hos ellers friske barn født til termin (8). Det er imidlertid viktig å være oppmerksom på den økte sårbarheten hos barn født nær grensen for prematuritet $(4,9)$. I takt med dette har retningslinjene for utredning og behandling av nyfødte med risiko for eller allerede utviklet hyperbilirubinemi vært $\mathrm{i}$ endring.

I årene 1988-93 ble lysbehandling og utskiftningstransfusjoner foretatt etter retningslinjer publisert av Bratlid i 1986 (10). Disse fungerte i stor utstrekning som nasjonal standard. Fra 1994 ble prosedyrene ved Sykehuset i Vestfold endret i henhold til skjema brukt ved Hillingdon sykehus, England, modifisert av Finlay \& Tucker $(5,11)$. I dette skjemaet aksepteres høyere bilirubinverdier som indikasjon for lysbehandling og utskiftningstransfusjon hos fullbårne barn. Fra og med 2007 har Norsk barnelegeforenings anbefalinger (vedtatt 2006) vært fulgt (12). Sistnevnte skjema angir samme indikasjoner for lysbehandling av normalvektige (fødselsvekt>2 $500 \mathrm{~g}$ ) som Hillingdon-skjemaet for barn født til termin (svangerskapsalder $>37$ uker), men er mer differensiert for barn med lav fødselsvekt.

Fra 2006 ble det innført generell screening av nyfødte for $\mathrm{ABO}$-immunisering.

Hensikten med denne artikkelen er å presentere data for hyperbilirubinemi, blodtypeimmunisering, lysbehandling og utskiftningstransfusjoner hos nyfødte ved Sykehuset i Vestfold i 21-årsperioden 1988-2008, og diskutere resultatene i lys av de endrede diagnostiske strategier og behandlingsindikasjoner i denne perioden.

\section{Materiale og metode}

Blodtypeimmuniseringer, lysbehandling og utskiftningstransfusjoner for hyperbilirubinemi hos nyfødte ble prospektivt registrert ved Sykehuset i Vestfold i 21-årsperioden 1988-2008 som ledd i neonatalseksjonens virksomhetsregistrering. Det ble utført årlige opptellinger med anonymisering av data. Prosjektet er et kvalitetssikringsprosjekt og godkjent av det lokale personvernombudet. Materialet ble analysert med utgangspunkt i tre kohorter: barn født ved sykehuset i 1988-93, 1994-2006 og 2007-08.

\section{Laboratoriediagnostikk}

Gravide ble undersøkt for RhD-immunisering og andre irregulære blodtypeantistoffer i henhold til nasjonale retningslinjer (13). Hos

\section{Hovedbudskap}

- Endrede retningslinjer for behandling av hyperbilirubinemi har ført til at færre fullbårne og flere premature barn lysbehandles

- Utskiftningstransfusjon foretas langt sjeldnere enn tidligere

- ABO-immunisering overses sannsynligvis i nesten halvparten av tilfellene hvis det ikke gjøres generell screening for tilstanden

- Det ble ikke påvist tilfeller av kjerneicterus i perioden 1988-2008 
Tabell 1 Nyfødte behandlet for hyperbilirubinemi i 21 -årsperioden 1988-2008

\begin{tabular}{|c|c|c|c|c|c|c|c|c|}
\hline & \multicolumn{2}{|c|}{$1988-93$} & \multicolumn{2}{|c|}{$1994-2006$} & \multirow{2}{*}{$\begin{array}{c}1994-2006 \text { mot } \\
1988-93 \\
\text { RR }(95 \% \mathrm{KI})\end{array}$} & \multicolumn{2}{|c|}{$2007-08$} & \multirow{2}{*}{$\begin{array}{c}2007-08 \text { mot } \\
1994-2006 \\
\operatorname{RR}(95 \% \mathrm{KI})\end{array}$} \\
\hline & $n$ & (\%) & $\mathrm{n}$ & $(\%)$ & & $n$ & $(\%)$ & \\
\hline Levende fødte & 14112 & & 27369 & & & 4092 & & \\
\hline Lysbehandlet (totalt) & 881 & $(6,2)$ & 1840 & $(6,7)$ & $1,08(1,00-1,16)$ & 195 & $(4,8)$ & $0,71(0,61-0,82)$ \\
\hline Fysiologisk hyperbilirubinemi & 579 & $(4,1)$ & 523 & $(1,9)$ & $0,47(0,42-0,52)$ & 48 & $(1,2)$ & $0,61(0,46-0,82)$ \\
\hline Prematuritetshyperbilirubinemi & 240 & $(1,7)$ & 1123 & $(4,1)$ & $2,41(2,10-2,77)$ & 122 & $(3,0)$ & $0,73(0,60-0,87)$ \\
\hline Blodtypeimmunisering & 62 & $(0,4)$ & 194 & $(0,7)$ & $1,61(1,21-2,14)$ & 25 & $(0,6)$ & $0,86(0,57-1,30)$ \\
\hline Utskiftningstransfusjon (totalt) & 31 & $(0,2)$ & 5 & $(0,02)$ & $0,08(0,03-0,21)$ & 1 & $(0,02)$ & $1,34(0,21-8,63)$ \\
\hline ABO-immunisering & 20 & $(0,14)$ & 0 & (0) & - & 1 & $(0,02)$ & - \\
\hline Rh-immunisering & 8 & $(0,06)$ & 3 & $(0,01)$ & $0,19(0,06-0,67)$ & 0 & (0) & - \\
\hline Annet & 3 & $(0,02)$ & 2 & $(0,01)$ & $0,34(0,07-1,72)$ & 0 & (0) & - \\
\hline
\end{tabular}

RhD-positive gravide som ikke har irregulære blodtypeantistoffer, utføres det kun én blodtypeserologisk undersøkelse ved tidlig svangerskapskontroll. RhD-negative kvinner screenes i tillegg med henblikk på irregulære blodtypeantistoffer i svangerskapsuke $32 \mathrm{og}$ 36. Dersom mor var RhD-negativ, ble navlestrengsblod tatt til bestemmelse av $\mathrm{Hb}$, blodtyping og direkte antiglobulintest ved fødselen. Blodtypeimmunisering ble diagnostisert hvis direkte antiglobulintest var positiv. Ved blodtypekonstellasjon med mulighet for både $\mathrm{ABO}-$ og RhD-immunisering ble tilstanden klassifisert som $\mathrm{RhD}$-immunisering hvis antiD var påvist hos den gravide og direkte antiglobulintest var sterkt positiv (grad 4+). Hvis mor hadde blodtype $\mathrm{A}, \mathrm{B}$ eller $\mathrm{AB}$, eller var $\mathrm{RhD}$-positiv, ble det ansett å foreligge annen blodtypeimmunisering enn i ABO-systemet eller overfor $\mathrm{RhD}$-antigenet.

I utredning av klinisk icterus ble det rutinemessig gjort ABO-typing samt direkte antiglobulintest hos barnet hvis mor var blodtype O. I en ettårsperiode 1996-97 ble alle nyfødte rutinemessig screenet for blodtypeimmunisering med blodtyping og direkte antiglobulintest som ledd $\mathrm{i}$ et forskningsprosjekt (14). På bakgrunn av studier som indikerer at udiagnostisert blodtypeuforlikelighet kan være en risikofaktor for kjerneicterus og alvorlig hyperbilirubinemi $(1,3$, 15), har man siden 2006 utført generell screening av nyfødte for ABO-immunisering ved sykehuset (blodtyping og direkte antiglobulintest i navlestrengsblod ved alle fødsler hvor mor har blodtype O).

Lysbehandling og utskiftningstransfusjon Alle barn som gjennomgikk lysbehandling eller utskiftningstransfusjon ble undersøkt med direkte antiglobulintest uansett blodtypekonstellasjon mellom mor og barn. Hvis testen var negativ, ble tilstanden klassifisert som «fysiologisk» hyperbilirubinemi når barnet var født til termin, og prematuritetshyperbilirubinemi hvis barnet var født prematurt (svangerskapsalder < 37 uker), og grensen for behandling i henhold til gjeldende retningslinjer var overskredet. I sammen- stilling av resultatene ble det i lysbehandlingsgruppene ikke inkludert pasienter hvor slik behandling ble gitt før og/eller etter utskiftningstransfusjon.

\section{Statistikk}

Da materialet er komplett, er de registrerte endringene reelle. Sammenlikning mellom grupper ble derfor gjort ved beregning av relativ risiko (RR) og $95 \%$ konfidensintervall $(95 \% \mathrm{KI})$.

\section{Resultater}

Det totale antall levende fødte i hele studieperioden var 45573 . Tabell 1 viser antall levende fødte og antall barn som ble lysbehandlet eller behandlet med utskiftningstransfusjon i perioden 1988 til 2008.

I totalpopulasjonen ble det diagnostisert 1287 tilfeller med blodtypeimmunisering (2,8\%). Av disse hadde 1073 (83\%) ABOimmunisering, 141 (11\%) RhD-immunisering, og 73 (6\%) andre former for immunisering. Utskiftningstransfusjon ble foretatt hyppigere ved $\mathrm{RhD}$-immunisering (11/141; $7,8 \%)$ enn ved ABO-immunisering (21/1 073; 2,0\%) (RR 3,99; $95 \%$ KI 1,98-7,95). Lysbehandling ble gitt til 237 (22\%) pasienter med ABO-immunisering, 31 (22\%) med $\mathrm{RhD}$-immunisering og 13 (18\%) med andre former for immunisering. ABO-immunisering ble diagnostisert betydelig hyppigere $\mathrm{i}$ årene hvor generell screening for slik blodtypeimmunisering ble gjennomført (1996-97 og 2006-8), enn når tilstanden ble diagnostisert som ledd i utredning av klinisk icterus (henholdsvis $309 / 8$ 598; 3,6\% og 764/36 975; 2,1\%) (RR 1,74; 95\%KI 1,53-1,98). Insidensen av ABO-immunisering var stabil (variasjonsbredde 3,1-3,9\%) i de fire årskohortene som har vært gjenstand for screening. Det ble ikke diagnostisert noe tilfelle av kjerneicterus.

\section{Diskusjon}

\section{Lysbehandling}

Andelen nyfødte som ble lysbehandlet for hyperbilirubinemi var uendret inntil 2007. Det skjedde imidlertid et skifte etter innfø- ring av nye retningslinjer fra 1994. Insidensen av fullbårne nyfødte som ble lysbehandlet falt markert, med tilsvarende økning for premature. Ekstrapoleres våre tall til hele landet (50 000 barn årlig født til termin), betyr det at endringene foretatt i 1994 ville redusert antall barn lysbehandlet for fysiologisk hyperbilirubinemi fra 2050 til 950 per år, med ytterligere reduksjon til 600 per år etter innføring av Norsk barnelegeforenings retningslinjer fra 2007. Dette betyr færre forstyrrende intervensjoner i en følsom tilknytningsfase mellom mor og barn de første dagene etter fødselen, og rasjonalisering av ressursbruken - uten at flere tilfeller av kjerneicterus oppstår. Overensstemmende med dette har nylig publiserte nasjonale data fra USA vist fallende insidens av kjerneicterus i årene 1988-2005 (16). «A kinder and gentler approach» til diagnostikk og behandling $\mathrm{i}$ henhold til nye retningslinjer fra 1994 (17) førte ikke til ny økning av kjerneicterus.

Det er vanskelig å dokumentere helsemessige konsekvenser av de mer liberale lysbehandlingsindikasjonene for premature. Tatt $\mathrm{i}$ betraktning at premature utgjør en risikogruppe (umoden blod-hjerne-barriere, mer umoden leverfunksjon og høyere komorbiditet), kan det synes riktig å ha en mer offensiv holdning til behandling av disse barna.

\section{Utskiftningstransfusjoner}

Antall utskiftningstransfusjoner har gått kraftig ned. Dette beror dels på en høyere behandlingsterskel i retningslinjene etablert i 1994, og trolig også noe på optimalisering av lysbehandlingen (mer effektive lamper, flere lamper samtidig ved alvorlig hyperbilirubinemi) samt bruk av intravenøst immunglobulin ved blodtypeimmunisering med raskt stigende bilirubinnivå (18). Sistnevnte behandlingsprinsipp gir trolig en uspesifikk blokade av Fc-reseptoren hos celler i det retikuloendoteliale system, som formodentlig er ansvarlig for destruksjon av antistoffmerkede erytrocytter (19). Utskiftningstransfusjon ble brukt relativt oftere ved RhD- enn ved ABO-immunisering, overens- 
stemmende med at førstnevnte tilstand representerer en mer alvorlig type immunisering. Utskiftningstransfusjon medfører risiko for til dels alvorlige komplikasjoner (4). Det bør derfor være strenge kriterier for denne prosedyren.

\section{Screening for blodtypeimmunisering}

Screening av gravide for irregulære blodtypeantistoffer, spesielt anti-D, har vært foretatt i en årrekke. Ved fødselen verifiseres RhD-immuniseringen med blodtyping av barnet og direkte antiglobulintest i navlestrengsblod. Barna følges nøye de første levedagene med henblikk på utvikling av behandlingstrengende hyperbilirubinemi. $\mathrm{ABO}$-immunisering forekommer imidlertid betydelig hyppigere enn $\mathrm{RhD}$-immunisering og fører til behandling med lys eller utskiftningstransfusjon hos langt flere barn enn ved $\mathrm{RhD}$-immunisering. Generell screening for $\mathrm{ABO}$-immunisering er ikke gjennomført analogt med screening for RhD-immunisering selv om ABO-immunisering har vært assosiert med kjerneicterus $(1,3)$. Våre data tyder på at uten screening for ABO-immunisering vil nesten halvparten av barna med en slik tilstand forbli udiagnostisert under sykehusoppholdet, med risiko for reinnleggelse for alvorlig hyperbilirubinemi.

Økningen i lysbehandling for blodtypeimmunisering (tab 1) kan delvis forklares av flere diagnostiserte tilfeller som følge av generell ABO-screening. Antall barn med påvist $\mathrm{ABO}$-immunisering $\mathrm{i}$ denne studien må imidlertid oppfattes som minimumstall i og med at negativ direkte antiglobulintest ikke sikkert utelukker ABO-immunisering. Høye maternelle IgG anti-A- og anti-B-titere kan, i tillegg til blodgruppering og direkte antiglobulintest, bidra til å predikere alvorlig hyperbilirubinemi hos ABO-inkompatible nyfødte (20). A foreta måling av IgG anti-Aog anti-B-titere som et generelt screeningprogram vil imidlertid være relativt ressurskrevende i forhold til tradisjonell blodtyping og direkte antiglobulintest.

\section{Kjerneicterus - ABO-immunisering}

Kjerneicterus er en potensielt meget alvorlig tilstand. Sløvhet, hypotoni og nedsatt sugelyst er reversible symptomer i startfasen, men kan progrediere til apnéepisoder, hypertoni, opistotonus og kramper. De fleste som overlever, vil utvikle irreversible nevrologiske tilstander som dyskinetisk cerebral parese, hørselstap og intellektuell funksjonshemning. I en nasjonal studie fra England ble det funnet kjerneicterus hos 13 av 1,4 millioner nyfødte, en insidens på 0,9/100 000 (3). ABO-immunisering var årsaken til ett av tilfellene. I en dansk studie forelå en blodtypekonstellasjon med mulighet for ABO-immunisering (mor blodtype $\mathrm{O}$ og barnet A eller B) hos fire av åtte barn med kjerneicterus (1). Immunisering var imidlertid ikke verifisert med positiv direkte antiglobulintest (Finn Ebbesen, Ålborg, personlig meddelelse). I en nyere dansk publikasjon beskriver Bjerre og medarbeidere mulig hemolytisk sykdom pga. ABO-inkompatibilitet som vanligste årsak til ekstrem hyperbilirubinemi hos nyfødte (15). Norske undersøkelser har vist at blodtype $\mathrm{O}$ hos mor er assosiert med behandlingstrengende hyperbilirubinemi hos barna $(6,9)$. ABO-typing av alle gravide har derfor vært anbefalt (21). Hvorvidt screening av nyfødte for $\mathrm{ABO}$-immunisering kan bidra til lavere insidens av kjerneicterus, er ikke avklart. Selv om et slikt program neppe er kostnadseffektivt (22), har man ved Sykehuset i Vestfold vektlagt de biologiske argumentene for slik screening $(1,3,15)$.

Årsakene til at kjerneicterus på nytt er blitt en aktuell problemstilling er flere. I den nevnte engelske undersøkelsen av Manning og medarbeidere (3) var risikoen for svært høye bilirubinnivåer og kjerneicterus knyttet til tidlig utskrivning fra sykehuset etter fødselen, ikke-hvit hudfarge, morsmelkernæring, dehydrering og ulike hemolytiske tilstander. Barn født på grensen mot prematuritet synes å være spesielt utsatt (4). Reduksjon i liggetiden i sykehus etter fødselen øker risikoen for reinnleggelse med behandlingstrengende hyperbilirubinemi (23). Disse risikofaktorene er omtalt $i$ en oversikt av Ruud Hansen (24). I vårt materiale ble det ikke registrert noe tilfelle av kjerneicterus, hvilket heller ikke var å forvente ut ifra tallmaterialets størrelse og en antatt insidens på $0,9-2,7 / 100000(3,16)$.

\section{Strategi for oppfølging}

Ved rutineundersøkelsen av nyfødte i barselavdelingen, og spesielt ved tidlig hjemreise, må barnet vurderes mht. risiko for utvikling av behandlingstrengende hyperbilirubinemi. Man må særlig være oppmerksom på fødselsvekt og svangerskapsalder, etnisitet, ernæring, vekttap og mulighet for immunisering. Hos barn med ikke-hvit hudfarge må serum-bilirubinkonsentrasjonen kontrolleres før hjemreise og ev. ved blodprøvetaking til nyfødtscreeningen for fenylketonuri og hypotyreose (ved 60 timers alder). Det samme gjelder hvis andre risikofaktorer for hyperbilirubinemi foreligger. Klinisk icterus må utredes. Transkutan bilirubinmåling er en skånsom og nyttig metode i denne sammenheng (25). God informasjon til foreldrene må vektlegges, både muntlig og skriftlig.

\section{Nye norske retningslinjer}

Norsk barnelegeforening anbefalte i 2006 nye retningslinjer for behandling av icterus hos nyfødte (12). Våre erfaringer etter to års bruk av disse tyder på at færre barn blir lysbehandlet sett i forhold til Sykehuset i Vestfolds retningslinjer fra 1994. Dette gjelder fysiologisk hyperbilirubinemi hos normalvektige barn så vel som prematuritetshyperbilirubinemi.

Oppgitte interessekonflikter: Ingen
Litteratur

. Bjerre JV, Ebbesen F. Genoptræden af kernikterus hos nyfødte børn i Danmark. Ugeskr Læger 2006: 168: 686-91.

2. Kernicterus in full-term infants - United States, 1994-1998. MMWR Morb Mortal Wkly Rep 2001 50: $491-4$.

3. Manning DJ, Maxwell MJ, Todd PJ et al. Prospective surveillance study of severe hyperbilirubinaemia in the newborn in the United Kingdom and Ireland. Arch Dis Child Fetal Neonatal Ed 2007; 92 F342-6.

4. Maisels JM, Newmann TB. Kernicterus in otherwise healthy, breast-fed term newborns. Pediatrics 1995: 96: 730-3.

5. Dodd KL. Neonatal jaundice - a lighter touch. Arch Dis Child 1993; 68: 529-33.

6. Newman TB, Klebanoff MA. Neonatal hyperbilirubinemia and long-term outcome: another look at the collaborative perinatal project. Pediatrics 1993; 92: $651-7$.

7. Newman TB, Maisels JM. Evaluation and treatment of jaundice in the term newborn: a kinder. gentler approach. Pediatrics 1992; 89: 809-18.

8. Newman TB, Liljestrand P, Jeremy RJ et al. Outcomes among newborns with total serum bilirubin levels of $25 \mathrm{mg}$ per deciliter or more. N Engl J Med 2006: 354: 1889-900

9. Volpe JJ. Bilirubin and brain injury. I: Volpe JJ, red Neurology of the newborn. Philadelphia: WB Saunders, 2001: 521-46.

10. Bratlid D. Fototerapi ved neonatal hyperbilirubinemi. Tidsskr Nor Lægeforen 1986: 106: 1830-3.

11. Finlay HVL, Tucker SM. Neonatal plasma bilirubin chart. Arch Dis Child 1978; 53: 90-1.

12. Subgruppen i nyfødtmedisin, Norsk Barnelegeforening. Norsk veileder for behandling av gulsott hos nyfødte. Oslo: Norsk Barnelegeforening, 2006.

13. Veileder for transfusjonstjenesten i Norge. 5. utgave. Oslo: Sosial- og helsedirektoratet, 2006.

14. Meberg A, Johansen KB. Screening for neonatal hyperbilirubinemia and $\mathrm{ABO}$ alloimmunization at the time of testing for phenylketonuria and congentital hypothyreosis. Acta Paediatr 1998; 87: 1269-74

15. Bjerre JV, Petersen JR, Ebbesen F. Surveillance of extreme hyperbilirubinaemia in Denmark. A method to identify the newborn infants. Acta Paediatr 2008; 97: 1030-4

16. Burke BL, Robbins JM, Bird TM et al. Trends in hospitalizations for the neonatale jaundice and kernicterus in the United States, 1988-2005. Pediatrics 2009. 123: 524-32.

17. American Academy of Pediatrics, Provisional Committee for Quality Improvement and Subcommittee on Hyperbilirubinemia. Practice parameter: management of hyperbilirubinemia in the healthy term newborn. Pediatrics 1994; 94 (4 pt 1): 558-65.

18. Huizing KM, Røislien J, Hansen TW. Intravenous immune globulin reduces the need for exchange transfusions in Rhesus and $\mathrm{ABO}$ incompatibility. Acta Paediatr 2008; 97: 1362-5.

19. Urbaniak SJ. ADCC (K cell) lysis of human erythrocytes sensitized with Rhesus alloantibodies. II. Investigation into mechanism of lysis. $\mathrm{Br} \mathrm{J}$ Haematol 1979: 42: 315-28.

20. Bakkeheim E, Bergerud U, Schmidt-Melbye A-C et al. Maternal IgG anti-A and anti-B titres predict outcome in ABO-incompatibility in the neonate. Acta Paediatrica 2009: 98: 1896-1901.

21. Heier HE, Fugelseth D, Lindemann $\mathrm{R}$ et al. Blodtype $\mathrm{O}$ hos mor som risikofaktor for behandlings trengende hyperbilirubinemi hos nyfødte. Tidsskr Nor Lægeforen 1996; 116: 34-6.

22. Han P, Kiruba R, Ong R et al. Haematolytic disease due to ABO incompatibility: incidence and value of screening in an Asian population. Aust Paediatr J 1988; 24: 35-8.

23. Lee K-S, Perlman M, Ballantyne M et al. Association between duration of neonatal hospital stay and readmission. J Pediatr 1995: 127: 758-66.

24. Hansen TW. Behandling av gulsott hos nyfødte. Tidsskr Nor Lægeforen 2005; 125: 594-8.

25. Meberg A, Wefring KW. Non-invasiv måling av serumbilirubin hos nyfødte. Tidsskr Nor Lægeforen 1984; 104: $970-2$ 